\title{
Os peregrinos ecléticos cristãos ${ }^{1}$
}

\author{
Gláucia Buratto Rodrigues de Mello*
}

resumo: $O$ artigo trata de quatro modalidades de peregrinações da tradição judaico-cristã. As peregrinações descritas e analisadas constituem marcos fundamentais na história da Fraternidade Eclética Espiritualista Universal (fundada pelo Mestre Yokaanam, em 1946, na cidade do Rio de Janeiro e que já conta com dezesseis filiais no Brasil e no exterior) e no estabelecimento da Cidade Eclética, criada em 1956 no planalto goiano e que é ainda hoje uma realidade. $\mathrm{O}$ artigo tem por base dados recolhidos e analisados em pesquisa teórica e etnográfica realizada pela autora na Cidade Eclética, comunidade rural religiosa que possui algumas centenas de irmãos da fraternidade.

palavras-chave: novos movimentos religiosos; peregrinações; comunidades neoesotéricas; Fraternidade Eclética Espiritualista Universal. abstract: This article shows four patterns of Jewish-Christian tradition pilgrimages. The description and analysis of these pilgrimages are fundamental marks on the history of Fraternidade Eclética Espiritualista Universal (created by Mestre Yokaanam, in 1946 in Rio de Janeiro and already with sixteen branches in Brazil and abroad). He also founded the Cidade Eclética in 1956 on the goiano plateau and still exists in the present days. The article is based on theoretical and ethnographic research made by the author in Cidade Eclética, which is a rural religious community where several hundreds of members live.

key-words: new religious movements; pilgrimages; neoesoteric communities; Fraternidade Eclética Espiritualista Universal.
* Graduada em letras (UFMG), antropóloga (UFPE) e socióloga (Université de Grenoble II), especialista em pesquisa sobre o imaginário milenarista, pesquisadora da FAPERJ, mantém sua linha de pesquisa sobre Movimento de Nova Era e comunidades neoesotéricas. É autora de vários artigos e do livro Millénarismes brésiliens : contribution à l'étude de l'imaginaire contemporain (Lille: ANRT, 2002, tese de doutorado).
Os dados que disponho aqui provêem principalmente de minha pesquisa de campo na Cidade Eclética, no distrito de Santo Antônio do Descoberto - GO. Permaneci no local de fevereiro a abril de 1998, realizando pesquisa durante o Doutorado. Dados complementares e atualizados também utilizados para este artigo provêem de pesquisa de campo realizada na Cidade Eclética durante a Semana Santa do ano de 2002, quando acompanhei a peregrinação que ocorre nessa época do ano. 


\section{Introdução}

A etimologia latina das palavras peregrinu e peregrinatione traduz a qualidade do estranho ou estrangeiro e a ação de viajar ou andar por terras distantes. Em termos simbólicos, aqueles termos traduzem um desprendimento e uma busca de natureza superior. $O$ ato de peregrinar representa fundamentalmente a situação transitória e transformadora do ser humano, a passagem de um estado ou de uma condição a outra, uma jornada interior. A caminhada do peregrino representa, em linhas gerais, a situação do homem de passagem sobre a Terra, a caminho da Terra Prometida ou do Paraíso Perdido (Chevalier \& Gheerbrant, 1990). De acordo com as pesquisas realizadas por Coleman e Elsner (1995) ${ }^{1}$, as peregrinações rituais sempre existiram. Em várias modalidades, religiosas ou não, de forma coletiva ou individual, elas constituem práticas reconhecidas tanto nas culturas simples quanto nas sociedades complexas. Dito de uma forma sintética, a peregrinação é antes de tudo uma busca, e o peregrino, um buscador.

Os estudos sobre o conjunto das práticas da peregrinação tentam identificar uma ordenação estrutural em termos de elementos e características em comum, no esforço de classificar o fenômeno sócioantropológico no âmbito das teorias sobre os rituais. Pesquisadores menos reducionistas admitem a dificuldade de cercar o fenômeno ao se levar em conta as modalidades de peregrinações, as motivações internas, individuais e as determinações históricas, sociais e

2 Citados por Carneiro (2003). religiosas que movem os peregrinos. No entanto, é possível identificar alguns modelos exemplares. No Ocidente, as peregrinações mais bem estudadas são aquelas que compõem o modelo judaicocristão no conjunto das práticas do catolicismo oficial ou popular.

Não tenho a intenção de realizar aqui um histórico ou um tratado sobre as modalidades de peregrinação, me propondo apenas a descrever e analisar quatro modalidades de peregrinação, observadas na gênese, no desenvolvimento e no conjunto dos rituais de uma comunidade religiosa. Vou descrever e analisar, portanto, modelos de peregrinação verificados na composição da figura messiânica do Mestre Yokaanam e na história da Fraternidade Eclética Espiritualista Universal (FEEU), por ele fundada. Teremos a oportunidade de verificar que as quatro modalidades são claramente inspiradas no modelo judaicocristão.

\section{O Mestre Yokaanam e a Fraternidade}

Para entendermos as motivações e o contexto das peregrinações que serão tratadas aqui, é preciso descrever, em linhas gerais, o surgimento do Mestre e da Fraternidade., A Fraternidade foi fundada na cidade do Rio de Janeiro, em 1946, em torno da pessoa de um aviador batizado Oceano de Sá, nascido em Maceió em 1911. Formado em escolas católicas, Oceano de Sá ingressou aos 18 anos no $20^{\circ}$ Batalhão de Caçadores, em Maceió, e logo (em 1930) foi transferido para a antiga Escola de Aviação na cidade do Rio de Janeiro. Dois anos mais tarde, estabeleceu- 
se em São Paulo, no Serviço de Comunicações Aéreas e Terrestres e, de lá, por ocasião da Revolução Constitucionalista, exilou-se na Bolívia e no Paraguai. Em Santa Cruz de la Sierra, deu continuidade às suas atividades de aviador como piloto dos Correios na rota para o Brasil, estabelecendose posteriormente em Corumbá.

Neste período, Oceano de Sá conheceu agentes da Condor, antiga companhia aérea subsidiária da alemã Lufthansa. Tendo recebido e aceito, dessa companhia, uma proposta de trabalho com treinamento na Alemanha, especializouse em vôo e pouso cegos (sem visibilidade). Fez outros cursos afins no período em que esteve fora do Brasil (de 1933 a 1937) e teve a oportunidade de viajar pelos EUA, Europa e Ásia. De volta ao Brasil, estabeleceu-se na cidade do Rio de Janeiro, trabalhando como piloto particular do então presidente Getúlio Vargas. Em 1944, sofreu grave acidente aéreo durante uma aula de instrução de vôo que ministrava a um aluno militar, provocado pela queda do bimotor em que ambos estavam. Esteve internado por dois meses e meio, em tratamento intensivo, e sobreviveu em circunstâncias milagrosas. À saída do hospital, Oceano de Sá abandonou definitivamente sua atividade profissional de aviador, bem como todas as outras atividades profanas, para dedicar-se integralmente à atividade religiosa missionária. Ele acabava de completar 33 anos de idade e adotava o nome Yokaanam, adquirido em batismo espiritual, antes do seu nome oficial. Yokaanam Oceano de Sá tornava-se o Mestre Yokaanam.
Sobre sua formação espiritual, da infância à idade adulta, Oceano de Sá teve formação católica, estudou a doutrina kardecista, através da qual desenvolveu qualidades mediúnicas excepcionais, e se interessou por antigas tradições esotéricas. Sua atividade profissional de aviador lhe permitiu realizar longas e diversas viagens. De acordo com os dados biográficos recolhidos, ele entrou em contato com ordens e mestres espirituais de diversos lugares do mundo, tendo freqüentado membros da Fraternidade Branca dos Monges Benares na Índia, monges trapistas no Deserto do Saara e lamas no Tibete. Pertenceu à Sociedade Esotérica da Comunhão do Pensamento e ao Conselho Nacional dos Maçons. Ocupou cargo na direção espiritual da Ordem Mística da Regeneração, no Rio de Janeiro, com a qual rompeu em 1942.

Nessa ocasião, arrastou consigo alguns simpatizantes dos seus ideais religiosos, afinados com suas práticas espíritas mediúnicas. Fundaram então uma pequena confraria para estudos espiritualistas e passaram a prestar serviços espirituais. Foi nesse contexto que, em 1944, sobreveio o acidente. Até aqui, ele era ainda Oceano de Sá. Tornou-se Yokaanam às vésperas do seu $33^{\circ}$ aniversário, idade em que Jesus Cristo passou a exercer a sua atividade missionária. O nome Yokaanam, a ele designado por "espíritos instrutores", é o nome grego de S. João Batista, distinguido do Yokanaam hebreu. Dois anos mais tarde, em 1946, ele fundava oficialmente a Fraternidade (FEEU) na cidade do Rio de Janeiro.

A Fraternidade é uma instituição religiosa de utilidade pública para a 
assistência social e espiritual eclética cristã ${ }^{3}$. Ela presta serviços assistenciais, com base na doutrina eclética, constituída pelo consórcio de orientações espirituais ecléticas e uma seleção de princípios e práticas cristãs, visando, em última instância, a restauração do cristianismo primitivo (original, dos primeiros tempos, preconizado por S. João Batista) e a reunião das religiões cristãs. Ao longo de dez anos de atividades assistenciais e espiritualistas (de 1946 a 1956) desempenhadas na cidade do Rio de Janeiro, a Fraternidade foi sendo consideravelmente ampliada ${ }^{4}$. Então, por "determinações espirituais", no ano de 1956, o templo que servia de sede à Fraternidade foi transferido da cidade do Rio de Janeiro para um certo ponto no extenso planalto central, onde seria fundada uma cidade sagrada.

Sempre de acordo com determinações espirituais que o Mestre Yokaanam e o grupo principal dos médiuns da Fraternidade recebiam, eles foram procurar uma determinada localidade no planalto goiano. As terras indicadas foram encontradas e compradas com recursos particulares e da

3 Em 1946, a FEEU abriu as portas de seus templos para a prática de passes espirituais (kardecistas ou da umbanda eclética cristã) e para a missa eclética cristã. De acordo com os recursos disponíveis, no interior do templo, prestavam serviços de enfermagem, distribuíam roupas, calçados, brinquedos e medicamentos.

4 O grupo embrionário era composto por menos de uma dezena de militares espíritas, além do Mestre Yokaanam. Em 1956, a FEEU já contava com cinco filiais além do templo principal e um corpo de associados em torno de 5 milmembros. Atualmente (2004), eles contam com catorze filiais no Brasil, uma no Paraguai e outra na Argentina. Não foi possível saber ao certo o número de adeptos da Fraternidade, mas acredito que ele seja bem menor, apesar do aumento do número de filiais. Não vou discutir aqui as razões para esse provável decréscimo, adianto apenas que, entre outras razões, eles não fazem mais o trabalho de proselistismo que faziam antes. instituição, além de doações e contribuições mensais dos associados. Efetivamente, uma cidade foi construída com muita determinação, sacrifício e poucos recursos ao longo de oito anos, distante apenas 60 quilômetros do que se tornou, alguns anos mais tarde, o centro de Brasília. Eles contam que, quando ali chegaram, em janeiro de 1956, não havia absolutamente nada. O projeto de Brasília ainda não tinha saído do papel. Tratava-se de terras praticamente despovoadas. Seguindo os planos espirituais, foi fundada no terreno uma comunidade rural cristã, onde se estabeleceu definitivamente a sede da Fraternidade, que ficou conhecida como Cidade Eclética ${ }^{5}$ : uma realidade presente ainda em nossos dias e que deverá continuar existindo, apesar das dificuldades econômicas pelas quais passam seus habitantes.

Um estilo de viver em comunidade e a formação esotérica interna, com inspiração na antiga tradição dos essênios, na maçonaria e no espiritismo mediúnico garantem a coesão do grupo, mesmo após a morte súbita do Mestre

5 No interior da Cidade Eclética moram em torno de 500 pessoas, em cerca de 150 residências individuais, construídas no sistema de mutirão, substituindo as barracas de lona que eles habitaram nos primeiros tempos. Algumas casas, umas mais simples, outras maiores e mais confortáveis, constituem patrimônio da FEEU. A cidade chegou a abrigar uma população bem maior nos seus primeiros anos, quando recebeu dezenas de crianças abandonadas, órfãs ou apenas carentes, de acordo com os projetos idealizados para a cidade. Por vezes essas crianças eram encaminhadas à cidade, acompanhadas por autorização de juízes de menores das cidades vizinhas, pelos próprios pais que não podiam criá-las, por utras, eram simplemente abandonadas às portas da cidade. Para recebê-las, foram construídos alojamentos. Esse programa existiu e funcionou por cerca de 20 anos e acabou se tornando inviável devido à escassez de recursos da comunidade e à falta de apoio do governo. No entanto, uma geração de crianças foi educada ali.

cadernos de campo - n. 12 - 2004 
Yokaanam em 1985, vítima de síncope cerebral (AVC). A Cidade Eclética foi planejada e tem seu projeto inspirado na recriação da cidade santa de Jerusalém. É uma Nova Jerusalém estabelecida no planalto central do Brasil. No alto de um dos poucos montes que existem na região, nas terras da Fraternidade, está o Monte Tábor, onde será construída a Igreja Eclética Universal, que acolherá os peregrinos cristãos do terceiro milênio e na qual será realizada a missão de unificação das religiões. A Cidade Eclética é uma realidade, mas a Nova Jerusalém e a Igreja Eclética são ainda uma utopia. Ainda que tenha prefeitura própria, a Cidade Eclética é distrito do município de Santo Antônio do Descoberto, no Estado de Goiás. Ela conta com algum apoio da prefeitura daquele município e do governo do Estado $^{6}$, mas, de acordo com as entrevistas que realizei, a Cidade Eclética se mantém de fato graças a doações que recebem e às cotas de contribuição financeira mensal ${ }^{7}$ dos seus associados.

A rotina da cidade é prevista e organizada, regulada por um esforço comunitário dos moradores da parte interna

6 O Estado contribui com o recurso do SUS para o hospital da cidade, que atende tanto seus moradores quanto os da periferia e, eventualmente, pacientes vindos de locais mais distantes em busca de tratamento médico mediúnico. A Prefeitura contribui com a contratação de alguns professores e com a merenda para o colégio de $1^{\circ}$ e $2^{\circ}$ graus que existe no interior da cidade (o qual atende igualmente moradores da cidade e da periferia) e provê também algum auxílio aos idosos, numerosos na cidade.

7 Aqueles que habitam o interior da Cidade Eclética trabalham como voluntários para a comunidade e vivem dos recursos da mesma; os que habitam fora dela, contribuem com cotas mensais fixas de valor reduzido. Em 2002, a cota era de $\mathrm{R} \$ 5,00$ mensais por associado. da cidade $^{8}$ e pela eventual colaboração de adeptos voluntários, que não moram no seu interior. As atividades comunitárias incluem os serviços ligados ao templo, ao hospital, à escola, à creche, ao hotel $^{9}$, à farmácia ${ }^{10}$, à agricultura de subsistência, à criação de reduzido gado leiteiro, avicultura e modesto comércio estabelecido na parte externa da cidade. A Cidade Eclética tem prefeito próprio, eleito dentre eles, responsável pelos assuntos administrativos; e tem também uma autoridade espiritual, igualmente eleita e reconhecida, responsável pelos assuntos religiosos. Desde que o Mestre Yokaanam não está mais "fisicamente" entre eles, a autoridade espiritual é representada por um presidente eleito numa espécie de Conselho de Anciãos, que responde como autoridade máxima.

8 A cidade é cuidadosamente isolada como espaço sagrado dentro do mundo profano, inteiramente cercada por muros ou cercas. Uma classificação estabelecida por eles distingue os irmãos internos aqueles que vivem dentro da cidade e dependem dos seus recursos - e os irmãos externos - que vivem fora dela, trabalham fora e contribuem mensalmente com uma cota fixa.

9 O que eles chamam hotel é, na verdade, um albergue muito simples que recebe adeptos em visita ou visitantes dos doentes internados no hospital da cidade.

10 A cidade conta com profissionais da fitoterapia, que manipulam ervas para produzir pomadas, xaropes e medicamentos variados, especialmente para uso interno do hospital ou para as receitas de natureza espiritual. Alguns medicamentos convencionais são vendidos a preço de custo na parte externa da cidade. No exercício da caridade cristã, a doutrina não visa o lucro e proíbe a circulação de dinheiro dentro da comunidade.

\section{artigos}




\section{As peregrinações}

\section{a) A peregrinação solitária ou vagabondage initiatique ${ }^{11}$}

Nas sociedades modernas e secularizadas, a atividade da errância pode denotar alienação ou uma reação contra a ordem da sociedade excludente, mecanizada e desumanizada; mas, no contexto de algumas tradições religiosas ou na experiência mística individual, essa prática pode ter valor iniciático, conotando uma via de reintegração do indivíduo com a sua essência sagrada. Essa modalidade de peregrinação tem como característica o fato de dar-se de forma solitária, errática - sem rota nem destino certos. Ela traduz uma busca pessoal, um período de recolhimento para o encontro com o sagrado, o despertar para uma consciência ampliada.

$\mathrm{Na}$ passagem da vida profana à religiosa, de Oceano de Sá a Mestre Yokaanam, o fundador da Fraternidade empreendeu uma peregrinação solitária, que se sucedeu ao longo período de sua internação no hospital. Encontramos justificativas e significados para essa peregrinação a partir de um conjunto de circunstâncias interessantes que se relacionam a alguns fatos e episódios extraordinários que, certamente, não passaram desapercebidos para a construção da figura missionária do Mestre Yokaanam. O primeiro deles é o grave acidente aéreo que Oceano de Sá sofreu e que representou um marco divisor em sua trajetória, separando a vida do aviador da do religioso e constituindo uma mudança de estilo de vida e comportamento. Acrescente-se a

11 Termo utilizado por M. Maffesoli e que dá subtítulo a uma de suas obras (cf. bibl.). esse acidente o fato de ele ter ocorrido às vésperas de seu $33^{\circ}$ aniversário, o que, certamente, diz muito a um homem formado na religião cristã e conhecedor de grandes tradições místicas e esotéricas.

Circunstâncias extraordinárias concorreram no acidente. A queda do bimotor no qual Oceano de Sá prestava serviço de carga e, ao mesmo tempo, ministrava uma aula de instrução de vôo a um certo Capitão Walmor ${ }^{12}$, foi efetivamente marcada pelo sobrenatural. Ainda que tivesse vários ossos quebrados, inclusive fratura craniana, Oceano conseguiu livrar-se do cinto de segurança, escapar pela janela do avião submerso e nadar algumas centenas de metros, antes de ser recolhido por um barco de salvamento. Foi o que ele contou a seus correligionários, num relato que foi transcrito em uma edição do jornal editado pela gráfica da FEEU ${ }^{13}$. De acordo com ele, sua sobrevivência deveu-se à ajuda de uma entidade espiritual que lhe surgiu nas águas: uma bela jovem de cabelos longos e vestida de azul veio em seu socorro e, apesar de vários ossos quebrados e outros graves ferimentos sofridos, ele pode nadar e ser salvo.

Para recuperar-se dos ferimentos, Oceano esteve internado em unidade de tratamento intensivo por dois meses e meio. Durante esse período e, de acordo com dados recolhidos em sua biografia, um último e decisivo acontecimento extraordinário determinou a sua transformação pessoal e espiritual: um

12 Não se sabe nada sobre esse senhor que faleceu no acidente. Apresentaram-me um pequeno recorte de jornal da época que noticiou o acidente, entre os documentos que tive a oportunidade de consultar na Cidade Eclética.

13 O Nosso, n. 556, ano 49, junho/1996, pp.5-7. 
sonho ou uma visão que ele teve no período de recuperação hospitalar. Esse sonho ou visão, de acordo com as mesmas fontes, dava continuidade a um primeiro, que lhe veio na infância (aos onze anos de idade), quando uma certa entidade espiritual apareceu-lhe e preveniu-o de que havia uma missão reservada para ele, mas que ele deveria aguardar o momento oportuno, quando ele seria instruído para ela. Essa mesma entidade reapareceu então para transmitir-lhe sua missão na Terra. Conforme já mencionei mais acima, na época do acidente, Oceano de Sá já havia composto um grupo para estudos e assistência espirituais. À saída do hospital, ao invés de voltar imediatamente para o seu grupo, ele desapareceu das vistas de seus companheiros espiritualistas e, durante algumas semanas, sem que soubessem do seu paradeiro, empreendeu sua peregrinação solitária ${ }^{14}$.

Sua peregrinação foi um caminhar sem destino, uma jornada interior para lugar nenhum, da mesma forma como Jesus retirou-se para o deserto a fim de orar ou entrar em contato com o sagrado. A missão de Yokaanam foi-lhe passada por uma entidade semelhante a Jesus Cristo. Essa entidade se apresentou com o nome de Mestre Lanuh e entregou-lhe a mensagem sobre sua missão: restaurar o cristianismo primitivo e unificar as religiões em torno dele. Para isso, a partir de então, Oceano deveria dedicar-se exclusivamente às atividades espiritual e missionária,

14 Todos esses dados foram recolhidos e resumidos a partir de documentos e literatura biográfica sobre Yokaanam disponíveis nas publicações da Fraternidade, nas entrevistas realizadas com ele em vida por outros pesquisadores (Negrão, 1984; Especho, 1984; Dias, 1974) e com base nas entrevistas que realizei durante minha pesquisas de campo. abandonando todas as outras atividades de natureza profana ${ }^{15}$. Com alguma resistência ${ }^{16}$, Oceano aceitou a missão e empreendeu a solitária peregrinação, antes de reencontrar o seu grupo e contar-lhes sobre a missão. Efetivamente, semanas mais tarde, ele se reapresentou a seu grupo e a outros grupos espiritualistas, anunciando a missão e seu novo nome de batismo: Yokaanam ${ }^{17}$, o solitário, apóstolo das religiões. Desde então, ele passou a usar a túnica longa amarrada à cintura $^{18}$, a calçar sandálias rústicas e deixou crescerem os cabelos e a barba. Os estudos sobre a crença e os movimentos messiânicos no Ocidente destacam a importância da crença judaica, ligada à chegada de um redentor da humanidade. Essa personalidade é um mensageiro, enviado em nome do Deus Pai ou de Jesus Cristo. Trata-se de um intermediário entre a divindade zelosa e a humanidade perdida. Antes e depois de Jesus Cristo, muitos foram os "enviados", falsos ou verdadeiros, ao longo da nossa história

15 Idem.

16 Consta na biografia do Mestre Yokaanam que, apesar da sua intenção de manter-se ligado a atividades religiosas e esotéricas, ele tinha outros planos para a sua vida. Ele teria resistido inicialmente à idéia de assumir a liderança de um grupo e de uma missão ecumênica, mas não ousou resistir, sobretudo depois das circuntâncias extraordiárias do acidente aéreo.

17 Por acreditar-se reencarnação de S. João Batista, o precursor do cristianismo primitivo, o nome Yokaanam foi-lhe dado em novo batismo, por tratarse de tradução do mesmo nome em grego, distinguido do Yokanaam, hebreu. A relação desse nome com a missão de restaurar o cristianismo é direta. Em termos civis, Oceano de Sá tinha ascendência grega pelo lado materno e holandesa pelo lado paterno, conforme ele teria declarado.

18 À maneira daquela que usavam Jesus Cristo, Moisés, S. Francisco de Assis e outros ministros da fé. Além de Yokaanam, essa roupa é usada por todos os irmãos da Fraternidade em trabalhos espirituais e denomina-se balandrau.

\section{artigos}


(Pereira de Queiroz, 1965). Via de regra, tratase de indivíduos iniciados na carreira eclesiástica, que, num dado momento, por razões particulares, abandonam a formação e passam a pregar voluntariamente, no exercício do catolicismo popular.

No processo de formação e apresentação desses redentores a uma coletividade, quatro passos exemplares têm sido invariavelmente identificados: eleição divina, provação, retiro e volta gloriosa ${ }^{19}$. A eleição tem como característica a ação do sobrenatural, imprimindo naquele indivíduo o que $\mathrm{M}$. Weber identificou e estudou como carisma, conferindo àquele que o possui poderes extraordinários, podendo ser interpretado como uma marca ou chamado divino. A provação envolve uma ruptura radical com um estilo de vida; via de regra, ela se impõe através de um grande sofrimento - doença física, mental ou espiritual, penúria material ou social, etc. O retiro sobrevém como um período de recolhimento, de retomada da consciência e encontro com o sagrado. Finalmente, a volta gloriosa apresenta o missionário pronto, trazendo a esperança da salvação.

Conscientemente construído ou confirmando mais uma vez esse processo, Oceano de Sá cumpriu os quatro passos, compondo com a sua peregrinação solitária a complementação da sua formação missionária. É difícil saber o que acontece nessa forma de peregrinação, já que se trata de uma jornada interior e que concerne exclusivamente aos mistérios espirituais, particulares ao peregrino. $\mathrm{O}$ Mestre

19 ALPHANDERY, Paul. "Notes sur le messianismemédiéval latin". Rapports annuels de la Section des Sciences Religieuses. École Pratiques des Hautes Études. Paris, 1898-1914 por PEREIRA DE QUEIROZ, 1965:8.
Yokaanam disse simplesmente que vagou pela periferia da cidade do Rio de Janeiro naquele período. Ainda que componha uma modalidade importante de peregrinação, ela não segue uma ritualística bem definida e, no caso de Yokaanam, ela não se repetiu, compondo apenas a formação da sua figura messiânica.

\section{b) As peregrinações apostólicas cristãs}

Essa modalidade de peregrinação tem caráter coletivo e tem por finalidade levar a palavra e o conforto espirituais e/ou materiais aos desamparados, na prática da caridade cristã. Com efeito, a fim de prestar assistência àqueles que não podiam se deslocar até o templo, e cumprindo o programa das atividades sociais e religiosas previstas pelos estatutos da Fraternidade, Yokaanam e um grupo determinado de irmãos da Fraternidade realizavam essa modalidade de peregrinação pela periferia da cidade do Rio de Janeiro. Elas ocorriam a cada ano durante os meses de novembro e dezembro. Duravam 54 dias, quando dezenas deles deixavam o templo e juntos caminhavam pela periferia da cidade, a fim de prestar assistência e difundir princípios cristãos.

De primeiro de novembro a 24 de dezembro, o grupo percorria a pé um circuito de aproximadamente 200 quilômetros, cobrindo o entorno do centro da cidade, parando de tempos em tempos, instalandose precariamente em acampamentos improvisados, que eles mesmos levantavam, em locais pré-determinados ao longo do trajeto estabelecido. $O$ percurso compreendia uma volta de $360^{\circ}$, tendo como pontos de

cadernos de campo $\cdot$ n. 12 - 2004 
partida e de chegada a sede da Fraternidade, estabelecida no centro da cidade do Rio de Janeiro. Durante a peregrinação, cada um dos irmãos da Fraternidade que participava dessa jornada vestia o balandrau e, calçando sandálias rústicas, caminhava, organizado em fila dupla. Eles levavam as bandeiras e os símbolos da Fraternidade, acompanhando a carismática figura do Mestre Yokaanam, que seguia à frente, reproduzindo conscientemente a personagem e o espírito de Jesus Cristo, seguido de perto por seus apóstolos. Da mesma forma que o seu modelo ${ }^{20}$, Yokaanam portava um grande cajado e fazia-se acompanhar de perto por um cordeiro.

O grupo caminhava lentamente, encorajando a adesão de outros por onde passavam, e era escoltado por um caminhão, que levava as provisões e todos os equipamentos necessários para o acampamento, e por uma ambulância, fundamental para a assistência médica que prestavam e para atender caso um peregrino se sentisse mal durante o percurso. Nos acampamentos, Yokaanam fazia pregações evangélicas, criticava as religiões pagãs e propagava princípios morais cristãos, além de realizar junto com os que o acompanhavam as mesmas atividades praticadas no templo: orientações e pequenas intervenções de natureza espiritual, passes magnéticos por

20 Durante uma pregação em templo espírita, em 26 de maio de 1951, perguntaram-lhe a razão pela qual ele se vestia como Jesus Cristo. Ele então respondeu: "Entendo que o Evangelho e o cristianismo significam um só roteiro que conduz infalivelmente a Ele... a menos que os homens cristãos continuem gentios à distância, entregues às orgias pagãs!... Eu, porém, pergunto ao mundo inteiro, para que me responda a céus aberto: "A quem devemos seguir e imitar? A Cristo ou a Satanás?..." Trechos de $O$ Cristianismo reúne não divide!, obra da autoria de Yokaanam editada pela Academia Eclética Esotérica (1a. edição em 1954). imposição das mãos, distribuição de medicamentos, brinquedos, roupas e calçados que eles conseguiam angariar graças às doações recebidas na sede ao longo dos meses precedentes.

Através desse gesto de caridade, eles pretendiam dar o exemplo do que fizeram os primeiros cristãos, os peregrinos da Boa Nova, levando conforto e esperança às pessoas abandonadas à própria sorte, ao mesmo tempo em que exerciam atividade proselitista, contando assim angariar simpatia e adesões. Essas peregrinações se repetiram da mesma forma ao longo de dez anos (de 1946 a 1956) e apresentavam uma ordenação ritualística bem definida, planejada com antecedência. Para tal, o percurso, o período, a duração, os objetos, os símbolos e a finalidade da peregrinação eram conscientemente observados, no desempenho de uma tarefa sagrada. Tratava-se de uma peregrinação nos moldes do cristianismo dos primeiros tempos.

\section{c) A peregrinação-êxodo}

\section{E Jeová disse a Moisés:}

"Estou para descer, a fim de livrá-los da mão dos egípcios e para fazê-los subir daquela terra para uma terra boa e espaçosa, para uma terra que mana leite e mel" (Êxodo, 3:8).

A peregrinação de 1956 constitui uma página, talvez a mais importante na história da Fraternidade, ficando para sempre relembrada como a "peregrinação-êxodo". Yokaanam teria recebido ordem e

\section{artigos}


instruções de "entidades espirituais superiores $^{21}$ " para que ela fosse realizada. Essas instruções diziam que ele devia afastar seu grupo da "escória e da vida culpável das sociedades urbanas". Com base em orientações espirituais precisas, eles deveriam deixar a cidade do Rio de Janeiro no período da peregrinação daquele ano, estabelecendo-se em local adequado (entenda-se com as qualidades espirituais necessárias), para a realização da missão que abraçaram. Pude conversar com um dos irmãos da Fraternidade que participou da "peregrinação-êxodo". Ele e todos aqueles que participaram e vivem ainda na cidade são carinhosamente chamados pelas demais pessoas da Fraternidade de "peregrinos". Já idoso, desde então vive na Cidade Eclética. Declarou-me em entrevista que participou da sessão mediúnica na qual foram recebidas as instruções que definiram a transferência do grupo para o planalto goiano, e disse-me que as instruções foram muito precisas quanto ao local onde deveriam se estabelecer.

De acordo com o seu relato, reafirmado em outras fontes consultadas, entre outros marcos, haveriam de encontrar no terreno um certo monte e, próximo deste, uma grande cruz de madeira. $\mathrm{E}$ foram em busca desses marcos, à procura da localidade em que se deu a visão que deu origem à crença na profecia de Dom Bosco e que, mais tarde, justificou e justifica ainda uma parte da concentração de espiritualistas diversos no planalto goiano. Conforme sabemos, o sonho visionário do monge italiano do

21 Reproduzo entre aspas expressões que Yokaanam e os irmãos da Fraternidade utilizam, sem me preocupar em investigar quais entidades seriam essas. Para mim, bastava a informação de que se tratava de entidades ligadas ao panteão eclético espiritual da Fraternidade. século XIX revelou que, naquela região, no coração do Brasil, junto a um lago, haverá de ressurgir "a Terra Prometida, donde manam leite e mel". A profecia de Dom Bosco foi popularizada na época do presidente Juscelino Kubitscheck, reforçando o projeto da construção de Brasília e tornou-se corrente no imaginário popular brasiliense. Mas, antes disso, a profecia já era conhecida por Yokaanam, que havia estudado em colégios católicos, junto aos padres salesianos (ordem fundada pelo mesmo D. Bosco).

Concorreu ainda para a escolha do local a crença na emergência de uma Grande Civilização, a civilização do terceiro milênio, que seria estabelecida no planalto central, no coração do Brasil. Trata-se de uma outra revelação, oriunda da religião espírita kardecista, difundida em obra mediúnica psicografada por Francisco Cândido Xavier e intitulada Brasil, coração do mundo, pátria do Evangelho. A obra traz um cuidadoso relato da história do Brasil em correspondência com os desígnios de Jesus Cristo, determinando missionários a seu serviço, alocados em posição de comando para conduzir o Brasil à "Pátria do Evangelho".

Enfim, Yokaanam deveria sair à procura das coordenadas indicadas, procura essa que foi facilitada por sua formação de aviador. Ele assim fez, acompanhado de dois ou três irmãos da Fraternidade, valendo-se inicialmente de um pequeno avião, depois de um velho jipe comprado especialmente para esse fim. Também caminharam bastante a pé. Foi assim que exploraram as vastas terras despovoadas do planalto goiano à procura do local indicado, até encontrarem uma antiga fazenda, junto 
da qual havia um certo monte, logo batizado Monte Tábor. Próximo desse monte encontraram a grande cruz de madeira. Pesquisas posteriores revelaram que aquela cruz tinha sido ali plantada no ano de 1722, quando da passagem de uma expedição bandeirante comandada por Bartolomeu Bueno da Silva. O terreno foi então comprado, como já mencionei antes, com os recursos da Fraternidade, dos associados e de todos aqueles que aderiram à decisão de transferirem-se para o planalto, com o propósito de lá viverem em comunidade, na Nova Jerusalém, "liberada do pecado, da perversão e da maldade" 22 . Além de uma cidade santa para servir de modelo, eles deveriam construir igualmente uma igreja universal, a "Igreja Eclética da Religião Única e Verdadeira".

A fim de concretizarem aquele ideal, todos os irmãos que se sentissem compelidos à adesão deveriam preparar-se para aquela peregrinação, deixando suas atividades profanas para se dedicarem exclusivamente à "obra de restauração do cristianismo primitivo". Todos os detalhes da peregrinação-êxodo foram cuidadosamente planejados com antecedência e partilhados entre os irmãos interessados, a fim de que fizessem uma escolha consciente e se preparassem devidamente para ela. Uma peregrinação-êxodo, conforme o termo sugere, é realizada por uma coletividade e envolve um deslocamento emigratório, com objetivos e destino bem definidos. A peregrinação-êxodo da Fraternidade teve como referência exemplar a peregrinação empreendida por Moisés, à frente do povo hebreu, do cativeiro no Egito à Terra Prometida.

22 Essa expressão e as anteriores foram utilizadas pelo Mestre Yokaanam e pelos irmãos da Fraternidade.
A peregrinação-êxodo da Fraternidade foi realizada ao longo de quatro dias, tendo início no dia primeiro de novembro de 1956, a zero hora, quando setenta e seis famílias, num total aproximado de trezentos obreiros $^{23}$, embarcaram em seis ônibus, saídos da cidade do Rio de Janeiro com destino à cidade de Barra Mansa (RJ). De lá tomaram um trem com destino a Anápolis $(\mathrm{GO})^{24}$. Em Anápolis, ônibus e caminhões os aguardavam para conduzilos, na última etapa da longa viagem, até o local de destino, então denominado Fazenda Campo Limpo. Chegaram ao local no dia quatro de novembro, às 14 horas. Na última etapa da viagem, embarcados em ônibus e caminhões, todos seguiram as orientações espirituais e a liderança de Yokaanam e desembarcaram para vencerem, a pé, o último quilômetro antes de chegarem ao destino final. Exaustos da longa viagem, vestindo todos os seus balandraus, eles se organizaram, como de costume, em longa fila dupla, tendo à frente o Mestre Yokaanam, as bandeiras e as insígnias da Fraternidade. Alguns desses peregrinos são vivos $^{25}$ e contam fragmentos da memória daquele dia chuvoso em que chegaram ao planalto. As dificuldades foram imensas, como podemos imaginar. Não havia nada no terreno. $\mathrm{O}$ ato solene de fundação da

23 Há diferenças quanto a esse número. A maior parte das fontes consultadas conta 76 famílias, mas Yokaanam declarou igualmente que a "caravana" para a Fazenda Campo Limpo arrastou 300 famílias, perto de 630 pessoas.

24 Essa linha existiu por pouco tempo, não existe mais.

25 No ano de 2002, do grupo pioneiro que realizou a peregrinação-êxodo, viviam ainda, inteiramente dedicados à instituição e à espiritualidade, 21 peregrinoss. O mais novo deles participou da peregrinação-êxodo com apenas oito anos de idade e o mais idoso contava, naquele ano, 89 anos de vida. 
cidade foi acompanhado pela imprensa ${ }^{26}$ com o enterro simbólico do cajado do Mestre Yokaanam.

Logo, eles davam início à armação de barracas de lona, onde ficaram instalados nos primeiros tempos. A chuva persistiu por três $\operatorname{dias}^{27}$, dificultando ainda mais os trabalhos, mas, ao mesmo tempo, lavandolhes as almas e as máculas do estilo de vida urbano, que eles deixavam para trás, e reforçando ainda mais o valor simbólico daquele ideal comunitário religioso. $\mathrm{Na}$ seqüência, eles começaram por construir a cozinha e a lavanderia comuns, o templo, o hospital, a escola, as primeiras casas e a ermida no alto do Monte Tábor, onde futuramente será construída a Igreja Eclética Universal. Os trabalhos foram todos realizados em regime de mutirão, com os recursos dos quais dispunham.

A peregrinação-êxodo foi realizada com tranqüilidade, em clima fraterno e de cooperação mútua. Pouco tempo depois, Brasília começava a ser construída, a 60 quilômetros dali. Yokaanam e os obreiros da Fraternidade tinham orgulho em dizer que viram e ajudaram Brasília a nascer e a crescer, uma vez que os caminhões passavam e se atolavam nas terras da

26 Revista Time, de Londres, Life, de Nova York e pelo jornal Última Hora do Rio e de São Paulo (Yokaanam fala à Posteridade, livro de sua autoria, editado nas oficinas da Folha Carioca Edtora S.A., com a primeira edição em 1956).

27 Dias (1974:40-41) ressalta no seu trabalho a imaginação coletiva e dramática em relação à duração daquelas chuvas. De acordo com suas entrevistas, houve quem declarasse "Choveu vinte dias e vinte noites sem parar"; "choveu três meses sem parar"; "choveu sete meses sem parar". Com base nos textos consultados e nas entrevistas que realizei, a informação mais corrente foi de que choveu durante três dias e três noites, sem estiagem.
Fraternidade. Além disso, a pista de pouso e decolagem que foi construída na Cidade Eclética para auxiliar os primeiros trabalhos serviu ao transporte de carga e ao deslocamento de autoridades para Brasília, na ausência ou precariedade das estradas dos primeiros tempos. Aqueles que vieram para o planalto deixaram para trás suas atividades urbanas e adotaram um estilo de vida rural, em comunidade cristã. A peregrinação-êxodo teve apenas uma edição.

\section{d) As peregrinações ao Monte Tábor}

E Jeová disse a Moisés,

Porque mostrarei estar contigo, e este é o sinal para ti de que sou quem te enviou: Depois de teres feito o povo sair do Egito, servireis o Deus neste monte (Êxodo, 3:12).

As peregrinações ao Monte Tábor substituíram as peregrinações apostólicas cristãs na Cidade Eclética. Da mesma forma que aquelas, estas são regulares e, por isso, bem planejadas, reguladas segundo um ritual conhecido de todos. Elas são realizadas coletivamente, tendo como ponto de partida e de chegada as portas do templo da Cidade Eclética. Os peregrinos da Fraternidade não levam mais a assistência à periferia; em vez disso, realizam uma longa caminhada até o Monte Tábor para um encontro consagrado à cúpula dos Mestres Espirituais, no topo do monte, onde realizam uma cerimônia simbólica. Também essa peregrinação recebe influência direta da tradição bíblica. 
A peregrinação ao Monte Tábor dura uma jornada diária - e ocorre sempre às quintas-feiras da Semana Santa - pelas terras da Fraternidade, num circuito interno que vai do templo ao monte e retorna do monte ao templo, num total aproximado de vinte quilômetros. Para essa longa caminhada são convocados todos os irmãos da Fraternidade (da sede-matriz e das filiais) e convidados simpatizantes, curiosos, personalidades públicas e a imprensa. A peregrinação tem início às 6 horas da manhã e termina ao cair da tarde, no interior do templo. Para realizá-la, são programadas algumas paradas para oração, descanso, lanche e almoço; essas refeições são simples, previamente preparadas por alguns deles, escalados para este fim, e oferecidas indistinta e gratuitamente a todos os peregrinos.

A peregrinação ao Monte Tábor envolve uma ritualística complexa, simbolicamente rica em significados. Os membros do silogeu espiritual (conselho de anciãos responsável pela autoridade espiritual da Fraternidade) cuidam para que o ritual seja preservado conforme a tradição, tal qual Yokaanam o realizava. Para essa ocasião, o Conselho Espiritual Administrativo elege os obreiros que conduzirão, à frente, a flâmula dos Peregrinos da Eternidade e as bandeiras do Brasil, da Fraternidade e da Juventude Eclética. Logo atrás vêm outros, carregando as imagens do arcanjo São Miguel, de Nossa Senhora da Conceição e de Buda. Vale dizer algo sobre o simbolismo dessas três personalidades. Miguel, o "Príncipe dos arcanjos", representado armado de escudo e espada, porque é guerreiro de Deus, pertence à milícia celestial, combate o mal, protege a peregrinação e a Fraternidade. Nossa Senhora da Conceição, para eles, assimila diferentes tradições e significados: mártir do cristianismo, passada pela roda de navalhas e decapitada, Myriam de Nazareth, Santa Catarina de Alexandria, Yanci e Yemanjá. Na peregrinação, ela representa a Mãe de Jesus. Quanto a Buda, ele é reconhecido na Fraternidade enquanto mestre espiritual, um dos maiores missionários divinos.

Junto desses, dois sacerdotes carregam espadas e representam Mestres da Cúpula Sagrada da Fraternidade Universal; eles são também encarregados da segurança espiritual da peregrinação. Em vida, era Yokaanam quem vinha em seguida - após a flâmula, as bandeiras, as imagens e as espadas. Com a sua morte, sua presença foi substituída pela dos membros do Conselho Espiritual Administrativo, seguidos hierarquicamente pelos membros da Hierofância do Sacro Colégio e depois, aos pares, pelos Irmãos Apóstolos e os Sacerdotes, os iniciados em geral, os adeptos, os neófitos e, por último, os simpatizantes, sempre bem-vindos.

Como de costume, os peregrinos são enfileirados dois a dois e apresentam-se vestidos com seus balandraus. À frente de todo o cortejo vai o "Pioneiro", que é o jipe no qual Yokaanam chegou e explorou a região, na década de cinqüenta, conservado como uma relíquia. Nesse dia, o Pioneiro leva equipamentos e o aparelho sonoro que dá o tom da peregrinação, reproduzindo os hinos da Fraternidade ao longo da jornada. Ao fim do cortejo segue a ambulância, caso os mais idosos sintamse cansados ou qualquer um dos peregrinos sintam um mal-estar durante a jornada. 
Quando todos chegam ao pé do Monte Tábor, considerado terreno sagrado, o cortejo, ainda organizado em fila, faz uma pausa para o hasteamento das bandeiras, junto a uma casa de apoio e a um segundo Pantheon ${ }^{28}$ pertencentes à Fraternidade. Em seguida, os membros do Conselho Espiritual Administrativo se dirigem para junto da cruz de madeira, igualmente conservada como relíquia no mesmo local. $\mathrm{Na}$ base da cruz, em torno dela, foram construídos em cimento sete discos concêntricos. Ali, reservadamente, ainda que não longe dos olhos de todos, eles entram em contato com a cúpula sagrada.

Feito isso, eles seguem para a última etapa da peregrinação: a subida ao topo do Monte Tábor, onde há uma ermida que será futuramente substituída pela Igreja Eclética Universal. À aproximação do cortejo, o corneteiro dá o toque que anuncia a sua chegada. As portas da ermida são então abertas para que todos entrem, ainda organizados. Cada um dos peregrinos mais graduados toma então o seu já conhecido lugar no interior da ermida. O presidente do Conselho de Anciãos, um sacerdote e um auxiliar do sacerdote dirigem-se à nave para realizar uma missa eclética, enquanto os demais sacerdotes ocupam o lado direito da nave e as sacerdotisas o lado esquerdo. Ocorre então o ofício religioso eclético, que é concluído com um ato simbólico: a soltura de uma pomba branca. Ao final desse rito todos dão graças, abraçam-se e, sem pressa, empreendem o caminho de volta.

28 Esse Pantheon é secundário em relação ao que foi construído no interior da Cidade Eclética. Ainda que em tamanho mais reduzido e aparentemente mais simples, ele reproduz aquele, em aparência e função, sendo aberto apenas nessa ocasião, quando os obreiros podem adentrá-lo para descansar e orar.

\section{Conclusão}

Essas modalidades de peregrinação baseiam-se num modelo da tradição judaico-cristã e representam cada um dos momentos mais importantes na história da Fraternidade e da comunidade religiosa reunida na Cidade Eclética. A primeira peregrinação determinou a passagem do homem Oceano de Sá ao messias Mestre Yokaanam. As peregrinações apostólicas, enquanto exemplo da prática cristã e exercício de proselitismo, angariaram simpatias e atraíram mais e mais adeptos, com vistas ao fortalecimento da instituição e à realização da missão. A terceira modalidade determinou a fundação da cidade santa no planalto goiano e, a última, compõe uma das atividades religiosas mais importantes na ritualística da Fraternidade na Cidade Eclética.

Passo a passo, cada uma das modalidades de peregrinação abordadas foram sendo substituídas, sendo que a última modalidade permanece com um rito anual do calendário da Cidade Eclética. As peregrinações urbanas e ritualísticas parecem não ter mais lugar em nossa sociedade moderna. Existe, no entanto, no fundo do coração dos irmãos ecléticos, a esperança de que a humanidade siga o exemplo deles e que a eles se juntem a fim de contribuir para a edificação da Nova Jerusalém e da Igreja Universal Eclética Cristã no planalto, fundando ou descobrindo ali a civilização do terceiro milênio, sonhada por D. Bosco. As peregrinações envolvem desprendimento material e uma atitude de humildade. Implicam despojamento, sacrifício e entrega em busca de algo maior: a vida eterna. 
Nesse sentido, a peregrinação é o verbo do caminho, da busca e do encontro plenos de provações e merecimento.

Artigo aceito para publicação em 18 de maio de 2004.

\section{Bibliografia}

CARNEIRO, Sandra M.C.S. Caminho de Santiago de Compostela: percurso, identidade e passagens. In: BIRMAN, P. (org.) Religião e espaço público. São Paulo: Attar Editorial, 2003a. p 259-281.

CARNEIRO, Sandra M.C.S. Rumo a Santiago de Compostela: os sentidos de uma moderna peregrinação. Tese de Doutorado, PPGSA/IFCS/UFRJ, Rio de Janeiro, 2003b.

CHEVAliER, J. e GHEERBRANT, A. Dicionário de símbolos. Rio de Janeiro: José Olympio Editora, 1990.

COLEMAN, S. e ELSNER, J. Pilgrimage: past and present in the world religions. Cambridge: Harvard University Press, 1995.

COUSINEAU, Phill. $A$ arte da peregrinação: para o viajante em busca do que the é sagrado. São Paulo: Agora, 1999.

DESROCHE, Henri. Sociologie de l'espérance. Paris: Calman-Lévy, 1973.

DIAS, Eurípedes C. Fraternidade Eclética Espiritualista Universal: tentativa de interpretação de um movimento messiânico. Dissertação de Mestrado. PPGAS/ UFRJ, Rio de Janeiro, 1974.
ELIADE, Mircea. O sagrado e o profano. Lisboa: Edição Livros do Brasil, s/d..

ELIADE, Mircea. La nostalgie des origines. Paris: Gallimard, 1971.

ESPEJO, L. Arturo. Rationalité et formes d'occupation de l'espace. Le projet de Brasilia. Paris: Ed. Anthropos: 1984.

FERREIRA, Aurélio B.H. Novo Dicionário da Lingua Portuguesa. Rio de Janeiro: Nova Fronteira.

GENNEP, A. van. Os ritos de passagem. Petrópolis: Vozes, 1978.

INTROVIGNE, Massimo. Les veilleurs de l'Apocalypse. Millénarisme et nouvelles religions au seuil de l'an 2000. Paris: Claire Vigne, 1996.

MAFFESOLI, Michel. Du nomadisme. Vagabondages initiatiques. Paris: Librairie Générale Française, 1997.

MANNHEIM, Karl. Idéologie et utopie. Paris: Librairie Marcel Rivière et Cie, 1956.

MELLO, Gláucia B. R. Milenarismo brasileiro: Novas gnoses, ecletismo religioso e uma nova era de espiritualidade universal. In: MUSUMECI, L. (org.). Antes do fim do mundo: sete estudos sobre milenarismos e messianismos no Brasil e na Argentina. Rio de Janeiro: Editora UFRJ, 2004a. p.103-118.

MELLO, Gláucia B. R. Millénarismes brésiliens: contribution à l'étude de 
l'imaginaire contemporain. Lille: ANRT, 2004b.

MELLO, Gláucia B. R. Millénarisme sur le plateau central du Brésil. La Création sociale. Sociétés cultures imaginaires. Grenoble, $\mathrm{n}$. 5, 2004c. p: 181-199.

MELLO, Gláucia B. R. Contribuições teóricas e metodológicas para o estudo do imaginário milenarista. Trabalho apresentado na $22^{\mathrm{a}}$ Reunião Brasileira de Antropologia. UNB, Brasília, 2000.

MELLO, Gláucia B. R. Ecletismo religioso. Acomodação para uma nova era de espiritualidade universal. Trabalho apresentado no $23^{\circ}$ Encontro Anual da ANPOCS. Caxambu, 1999a.

MELLO, Gláucia B. R. Imaginário milenarista brasileiro. Trabalho apresentado nas IX Jornadas sobre Alternativas Religiosas na América Latina, IFCS/UFRJ, Rio de Janeiro, 1999b.

MELlO, Gláucia B. R. Aspectos do milenarismo contemporâneo brasileiro. Trabalho apresentado na $21^{\mathrm{a}}$ Reunião Brasileira de Antropologia. UFES, Vitória, 1998.

MELLO, Gláucia B. R. Os cristãos ecléticos do terceiro milênio. A Nova Jerusalém no Planalto Goiano (no prelo).

NEGRÃO, Lísias N. e CONSORTE, J.G. O messianismo no Brasil contemporâneo. São Paulo: FFLCH/CER: Col. Religião e Sociedade Brasileira, 1, 1984.
OLIVEIRA, Juscelino K. Por que construi Brasília. Rio de Janeiro: Bloch Editora, 1975.

PEREIRA DE QUEIROZ, M.I. Réforme et révolution dans les sociétés traditionnelles. Histoire et ethnologie des mouvements messianiques. Paris: Ed. Anthropos, 1968.

PEREIRA DE QUEIROZ, M.I. O messianismo no Brasil e no mundo. São Paulo: Dominus, 1965.

SERVIER, Jean. Histoire de l'utopie. Paris: Gallimard, 1967.

WEBER, Max. Economie et société. Paris: Plon, 1995.

XAVIER, Francisco C. Brasil, coração do mundo, pátria do Evangelho. Rio de Janeiro: Federação Espírita Brasileira, $22^{a}$ edição. 